\title{
All-Soluble All-Iron Aqueous Redox-Flow Battery
}

\author{
Ke Gong, ${ }^{\dagger}$ Fei Xu, ${ }^{\dagger}$ Jonathan B. Grunewald, ${ }^{\dagger}$ Xiaoya Ma, ${ }^{\dagger}$ Yun Zhao, ${ }^{\dagger}$ Shuang Gu, ${ }^{*},{ }^{*}$ and Yushan Yan ${ }^{*}{ }^{\dagger}$ \\ ${ }^{\dagger}$ Department of Chemical and Biomolecular Engineering, University of Delaware, 150 Academy Street, Newark, Delaware 19716, \\ United States \\ ${ }^{\ddagger}$ Department of Mechanical Engineering, Wichita State University, 1845 Fairmount Street, Wichita, Kansas 67260, United States
}

\section{Supporting Information}

ABSTRACT: The rapid growth of intermittent renewable energy (e.g., wind and solar) demands low-cost and large-scale energy storage systems for smooth and reliable power output, where redox-flow batteries (RFBs) could find their niche. In this work, we introduce the first all-soluble all-iron RFB based on iron as the same redox-active element but with different coordination chemistries in alkaline aqueous system. The adoption of the same redox-active element largely alleviates the challenging problem of cross-contamination of metal ions in RFBs that use two redox-active elements. An all-soluble all-iron RFB is constructed by combining an iron-triethanolamine redox pair (i.e., $\left.[\mathrm{Fe}(\mathrm{TEOA}) \mathrm{OH}]^{-} /[\mathrm{Fe}(\mathrm{TEOA})(\mathrm{OH})]^{2-}\right)$ and an iron-cyanide redox pair (i.e., $\mathrm{Fe}(\mathrm{CN})_{6}{ }^{3-} / \mathrm{Fe}(\mathrm{CN})_{6}{ }^{4-}$ ), creating $1.34 \mathrm{~V}$ of formal cell voltage. Good performance and stability have been demonstrated, after addressing some challenges, including the crossover of the ligand agent. As

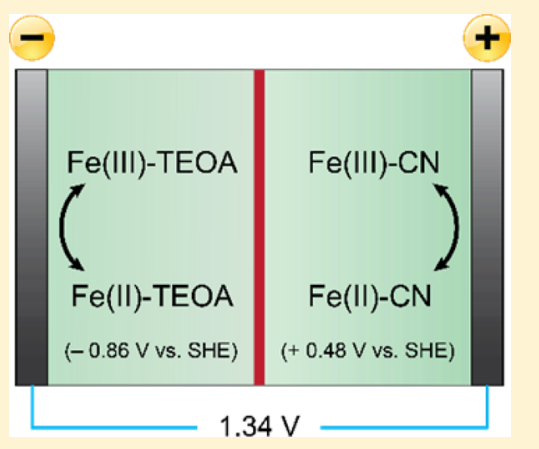
exemplified by the all-soluble all-iron flow battery, combining redox pairs of the same redox-active element with different coordination chemistries could extend the spectrum of RFBs.

$\mathrm{R}$ edox-flow batteries (RFBs) have been considered one of the most flexible systems for stationary energy storage owing to their decoupled energy and power. ${ }^{, 2}$ A typical RFB consists of two soluble redox pairs separated by an ion-exchange membrane (IEM). Designed for large-scale energy storage, RFBs are required to have low system cost and long service life. Unfortunately, the imperfect ionic selectivity of existing IEMs inevitably leads to undesired crossover of redox species between negative and positive electrolytes. Electrolyte contamination brought on by the crossover of redox species can cause permanent losses in both battery capacity and Coulombic efficiency (CE), seriously threatening the reliability and durability of RFBs. The crossover problem can be mitigated to a certain extent by using one mixed electrolyte as both negative and positive electrolytes. However, the use of mixed electrolytes often results in lowered cell voltage and increased material costs. ${ }^{3}$ An alternative approach is to use the same redox-active element to create the two redox pairs. Allvanadium (all-V) RFBs are an excellent example, and all-V RFBs use two vanadium-based redox pairs that fundamentally eliminate the problematic cross-contamination from two different redox-active elements and provide unlimited cyclability in theory. ${ }^{4}$ Largely because of the intrinsic tolerance to cross-contamination, significant efforts have been devoted to improving all-V RFBs for the past 3 decades, making them the most successful RFBs to date. However, one challenging issue for all-V RFBs is their high material cost that hinders their widespread deployment. Other RFBs based on the same redox- active elements with different valence states have been proposed, including all-chromium (all-Cr), all-iron (all-Fe), all-lead (all- $\mathrm{Pb}$ ), and all-copper (all-Cu) RFBs. ${ }^{5-8}$ In particular, all-Fe RFBs have advantages such as low chemical toxicity and very low material cost. ${ }^{9}$ The existing all-Fe RFB was pioneered by L. W. Hruska and R. Savinell as early as 1981, and that all-Fe RFB was constructed by the $\mathrm{Fe}^{2+} / \mathrm{Fe}$ redox pair and the $\mathrm{Fe}^{3+}$ / $\mathrm{Fe}^{2+}$ redox pair in negative electrolyte and positive electrolyte, respectively. ${ }^{9}$ It is a great invention; however, solid metallic iron is involved in negative redox reaction, and as such, the energy and power of this all-Fe RFB are no longer completely decoupled from each other. In addition, the deposition and dissolution of metallic iron on the negative electrode brings concerns over dendrite formation. Moreover, the hydrogen evolution reaction (HER) as a side reaction poses a serious challenge because the standard redox potential of $\mathrm{Fe}^{2+} / \mathrm{Fe}$ is $450 \mathrm{mV}$ more negative than that of HER at $\mathrm{pH}=0 .{ }^{9}$

An all-soluble all-Fe RFB may have the potential to address the issues associated with the participation of iron metal yet maintain the advantages from the same redox-active elements. It has been known that organic ligands can coordinate with many metal ions to form soluble redox pairs, which offers many possibilities for all-soluble, all-(redox-active) element RFBs. Many soluble redox pairs based on iron complexes have been

Received: April 5, 2016

Accepted: May 3, 2016

Published: May 3, 2016 
explored and are summarized in Figure 1 and Table S1 (Supporting Information), ${ }^{10-14}$ and herein, we present the first

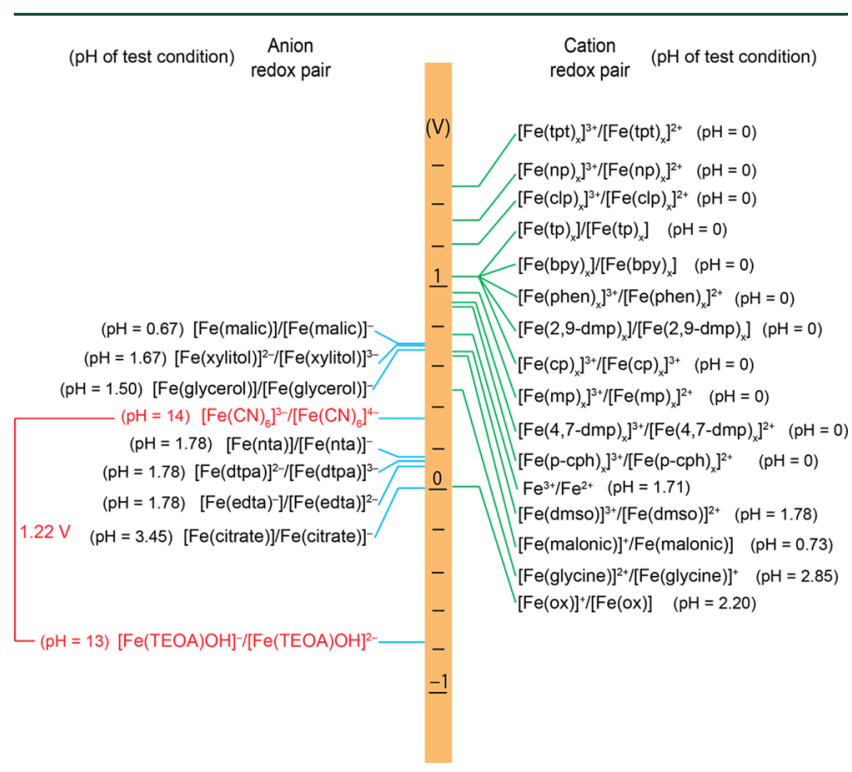

Figure 1. Redox pairs of iron complexes that have been tested for RFB applications. Each redox pair is represented by its formal potential versus SHE at the corresponding $\mathrm{pH}$ of its test conditions. The full names of any abbreviations are listed in Table S1. The highlighted $\left.[\mathrm{Fe}(\mathrm{TEOA}) \mathrm{OH}]^{-} / \mathrm{Fe}(\mathrm{TEOA})(\mathrm{OH})\right]^{2-}$ and $\mathrm{Fe}-$ $(\mathrm{CN})_{6}^{3-} / \mathrm{Fe}(\mathrm{CN})_{6}^{4-}$ redox pairs constitute the all-Fe RFB in this work.

example of an all-soluble all-Fe RFB by combining an irontriethanolamine redox pair (i.e., $\left[\mathrm{Fe}(\mathrm{TEOA}) \mathrm{OH}^{-} /[\mathrm{Fe}-\right.$ $(\mathrm{TEOA})(\mathrm{OH})]^{2-}$, denoted as $\left.\mathrm{Fe}-\mathrm{TEOA}\right)$, and an ironcyanide redox pair (i.e., $\mathrm{Fe}(\mathrm{CN})_{6}{ }^{3-} / \mathrm{Fe}(\mathrm{CN})_{6}{ }^{4-}$, denoted as $\mathrm{Fe}-\mathrm{CN})$ in a simple single-IEM cell configuration.

The Fe-TEOA redox pair is composed of two kinds of anions and has a redox potential of $-0.86 \mathrm{~V}$ versus SHE (formal potential, measured in $\mathrm{pH}=13$ ). The $\mathrm{Fe}-\mathrm{CN}$ redox pair is also composed of two kinds of anions and has a redox potential of $+0.36 \mathrm{~V}$ versus a standard hydrogen electrode (SHE, standard potential). The all-soluble all-Fe RFB based on
$\mathrm{Fe}-\mathrm{TEOA}$ and $\mathrm{Fe}-\mathrm{CN}$ as redox pairs is expected to have a standard cell voltage of $1.22 \mathrm{~V}$, slightly higher than that of the existing metallic Fe-based all-Fe RFB mentioned above (1.12 $\mathrm{V})$.

The corresponding redox reactions and electrode potentials are shown in eqs 1 and 2.

$$
\begin{aligned}
& {[\mathrm{Fe}(\mathrm{TEOA}) \mathrm{OH}]^{-}+\mathrm{e}^{-} \leftrightarrow[\mathrm{Fe}(\mathrm{TEOA})(\mathrm{OH})]^{2-}} \\
& \quad \varphi^{0^{\prime}}=-0.86 \mathrm{~V} \text { vs SHE } \\
& \mathrm{Fe}(\mathrm{CN})_{6}{ }^{3-}+\mathrm{e}^{-} \leftrightarrow \mathrm{Fe}(\mathrm{CN})_{6}{ }^{4-} \quad \varphi^{0}=+0.36 \mathrm{~V} \text { vs SHE }
\end{aligned}
$$

In addition to the slightly increased cell voltage, the standard rate constants on glassy carbon of Fe-TEOA $\left(6.3 \times 10^{-2} \mathrm{~cm}\right.$ $\left.\mathrm{s}^{-1}\right)^{5}$ and $\mathrm{Fe}-\mathrm{CN}\left(1.0 \times 10^{-1} \mathrm{~cm} \mathrm{~s}^{-1}\right)^{15}$ are also more facile than those of pristine $\mathrm{Fe}^{2+} / \mathrm{Fe}$ and $\mathrm{Fe}^{3+} / \mathrm{Fe}^{2+}$ redox pairs $(3.3 \times$ $10^{-9}$ and $1.2 \times 10^{-4} \mathrm{~cm} \mathrm{~s}^{-1}$, respectively), ${ }^{15,16}$ drastically lowering the electrode overpotential.

All-soluble redox pairs, high cell voltage, and facile kinetics make this $\mathrm{Fe}-\mathrm{TEOA}$ - and $\mathrm{Fe}-\mathrm{CN}$-based all-Fe RFB a possible candidate for renewable energy storage and warrant consideration for development. Not limited to this example, as shown in Figure 1, there are many other possibilities to construct an all-soluble all-Fe RFB (note that a multiple-IEM cell configuration is required when using redox pairs with opposite charges $^{17,18}$ ).

The standard potential of the $\mathrm{Fe}(\mathrm{CN})_{6}{ }^{3-} / \mathrm{Fe}(\mathrm{CN})_{6}{ }^{4-}$ redox pair is $0.36 \mathrm{~V}$ versus $\mathrm{SHE}$; however, the formal potential depends on the ionic strength of the solution and can reach around $0.44 \mathrm{~V}$ versus $\mathrm{SHE}$ in a solution with an ionic strength equivalent to a $0.5 \mathrm{M}$ salt solution. ${ }^{19}$ As shown in cyclic voltammetry $(\mathrm{CV})$ of the two redox pairs, the formal-potential difference between the two redox pairs is $1.34 \mathrm{~V}$ (Figure 2a).

$\mathrm{CVs}$ at different scan rates were also taken to measure the standard rate constant of the $[\mathrm{Fe}(\mathrm{TEOA}) \mathrm{OH}]^{-} /[\mathrm{Fe}(\mathrm{TEOA})-$ $(\mathrm{OH})]^{2-}$ redox pair and the diffusion coefficient of each species, based on the Randles-Sevcik equation and Nicolson method, respectively (Supporting Information, Figure S1). The results are listed in Table 1 . Both the diffusion coefficients and standard rate constant measured in this work are comparable to
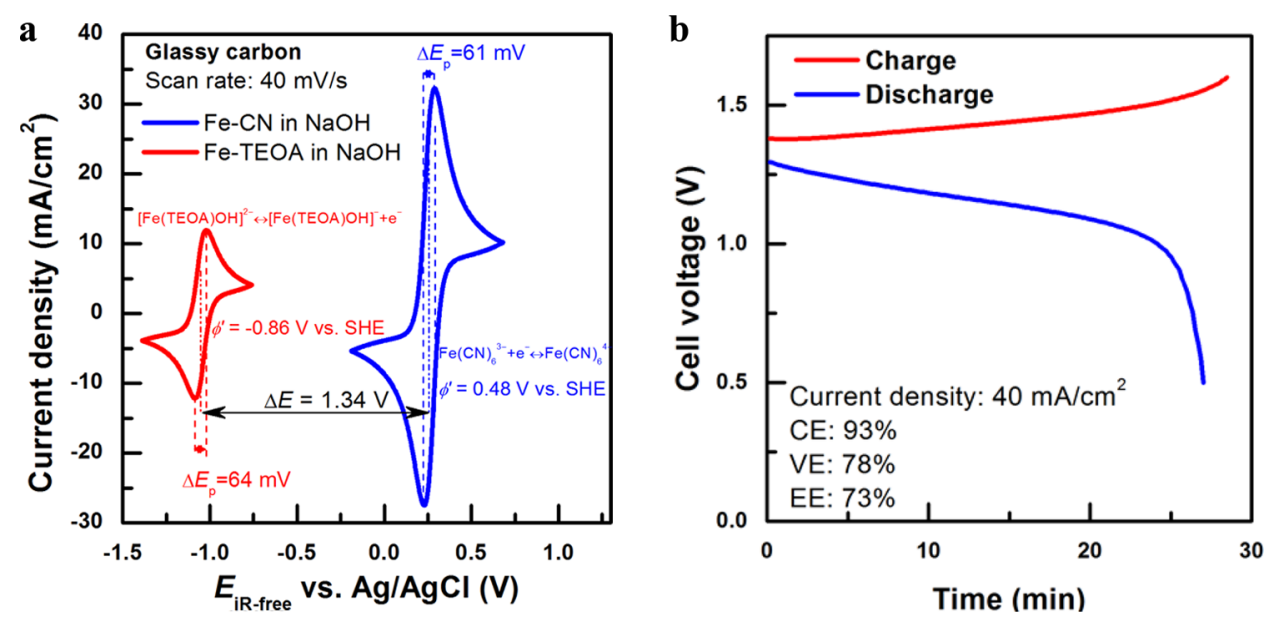

Figure 2. (a) $\mathrm{CV}$ of $[\mathrm{Fe}(\mathrm{TEOA}) \mathrm{OH}]^{-} /[\mathrm{Fe}(\mathrm{TEOA}) \mathrm{OH}]^{2-}$ and $\mathrm{Fe}(\mathrm{CN})_{6}{ }^{3-} / \mathrm{Fe}(\mathrm{CN})_{6}{ }^{4-}$ in sodium hydroxide solution. The $\mathrm{Fe}-\mathrm{TEOA}$ solution contains $0.2 \mathrm{M} \mathrm{FeCl}_{2}, 0.2 \mathrm{M} \mathrm{FeCl}_{3}, 2 \mathrm{M}$ TEOA, and $3 \mathrm{M} \mathrm{NaOH}$. The $\mathrm{Fe}-\mathrm{CN}$ solution contains $0.2 \mathrm{M} \mathrm{Na}_{4} \mathrm{Fe}(\mathrm{CN})_{6}, 0.2 \mathrm{M} \mathrm{Na} 3 \mathrm{Fe}(\mathrm{CN})_{6}$, and 3 $\mathrm{M} \mathrm{NaOH}$. The working electrode is glassy carbon, and the scan rate is $40 \mathrm{mV} / \mathrm{s}$ for both cases. (b) Cell voltage curve of a charge-discharge test of all-Fe RFB at $40 \mathrm{~mA} / \mathrm{cm}^{2}$. 
Table 1. Diffusion Coefficients of $[\mathrm{Fe}(\mathrm{TEOA}) \mathrm{OH}]^{-}\left(D_{\mathrm{O}}\right)$ and $[\mathrm{Fe}(\mathrm{TEOA}) \mathrm{OH}]^{2-}\left(D_{\mathrm{R}}\right)$ and the Standard Rate Constant $\left(k^{0}\right)$ of the $[\mathrm{Fe}(\mathrm{TEOA}) \mathrm{OH}]^{-} /[\mathrm{Fe}(\mathrm{TEOA}) \mathrm{OH}]^{2-}$ Redox Pair, Calculated from Cyclic Voltammograms of the Solution Containing Equal Concentrations of $[\mathrm{Fe}(\mathrm{TEOA}) \mathrm{OH}]^{-}$and $[\mathrm{Fe}(\mathrm{TEOA}) \mathrm{OH}]^{2-}$
$D_{\mathrm{O}}\left(\mathrm{cm}^{2} \mathrm{~s}^{-1}\right)$
$D_{\mathrm{R}}\left(\mathrm{cm}^{2} \mathrm{~s}^{-1}\right)$
$k^{0}\left(\mathrm{~cm} \mathrm{~s}^{-1}\right)$
$7.1 \times 10^{-7}$
$7.2 \times 10^{-7}$
$1.1 \times 10^{-2}$

the reported values in the literature $\left(1.6 \times 10^{-6} \mathrm{~cm}^{2} \mathrm{~s}^{-1}\right.$ and 6.3 $\left.\times 10^{-2} \mathrm{~cm} \mathrm{~s}^{-1}\right) .^{5}$

The facile kinetics of the $\mathrm{Fe}(\mathrm{CN})_{6}{ }^{3-} / \mathrm{Fe}(\mathrm{CN})_{6}{ }^{4-}$ redox pair has been well established. The diffusion coefficients and standard rate constant of the $\mathrm{Fe}(\mathrm{CN})_{6}^{3-} / \mathrm{Fe}(\mathrm{CN})_{6}^{4-}$ redox pair were also measured; the results are listed in Table 2.

Table 2. Diffusion Coefficients of $\mathrm{Fe}(\mathrm{CN})_{6}{ }^{3-}\left(D_{\mathrm{O}}\right)$ and $\mathrm{Fe}(\mathrm{CN})_{6}^{4-}\left(D_{\mathrm{R}}\right)$ and the Standard Rate Constant $\left(k^{0}\right)$ of the $\mathrm{Fe}(\mathrm{CN})_{6}{ }^{3-} / \mathrm{Fe}(\mathrm{CN})_{6}{ }^{4-}$ Redox Pair, Calculated from Cyclic Voltammograms of the Solution Containing Equal Concentrations of $\mathrm{Fe}(\mathrm{CN})_{6}{ }^{3-}$ and $\mathrm{Fe}(\mathrm{CN})_{6}^{4-}$

$\begin{array}{ccc}D_{\mathrm{O}}\left(\mathrm{cm}^{2} \mathrm{~s}^{-1}\right) & D_{\mathrm{R}}\left(\mathrm{cm}^{2} \mathrm{~s}^{-1}\right) & k^{0}\left(\mathrm{~cm} \mathrm{~s}^{-1}\right) \\ 8.6 \times 10^{-6} & 8.2 \times 10^{-6} & 2.5 \times 10^{-1}\end{array}$

The standard rate constants of $[\mathrm{Fe}(\mathrm{TEOA}) \mathrm{OH}]^{-} /[\mathrm{Fe}-$ $(\mathrm{TEOA})(\mathrm{OH})]^{2-}$ and $\mathrm{Fe}(\mathrm{CN})_{6}^{3-} / \mathrm{Fe}(\mathrm{CN})_{6}^{4-}$ are much greater than that of the $\mathrm{Fe}^{3+} / \mathrm{Fe}^{2+}$ redox pair in acid (e.g., $1.2 \times 10^{-4}$ $\left.\mathrm{cm} \mathrm{s}^{-1}\right),{ }^{15}$ suggesting much smaller overpotentials under the same conditions.

The all-soluble all-Fe RFB was assembled, and the chargedischarge test at $40 \mathrm{~mA} \mathrm{~cm}^{-2}$ current density is shown in Figure 2b. The CE, voltage efficiency (VE), and energy efficiency (EE) are 93,78 , and $73 \%$, respectively. Such an EE is higher than that of a traditional metallic iron-based all-Fe $\mathrm{RFB}\left(\mathrm{Fe}^{2+} / \mathrm{Fe}\right.$ vs $\left.\mathrm{Fe}^{3+} / \mathrm{Fe}^{2+}\right)$ reported, EE: $11-44 \%\left(60 \mathrm{~mA} \mathrm{~cm}{ }^{-2}\right) .{ }^{9}$ The successful charge-discharge test and good performance observed here clearly confirm the feasibility of an all-soluble all-Fe RFB.

The polarization curve of the all-soluble all-Fe RFB is shown in Figure 3. The peak power density reaches $160 \mathrm{~mW} \mathrm{~cm}^{-2}$. The discharge power density is higher than that of the traditional all-soluble all-Fe RFB $\left(\sim 120 \mathrm{~mW} \mathrm{~cm}^{-2}\right) .{ }^{9}$ Due to the facile kinetics of both redox pairs, the electrode overpotential is very small. The voltage and current density follow a typical ohmic relationship, indicating that the majority of the voltage loss comes from the large internal resistance.

Figure 4 shows 110 cycles of charge-discharge voltage curves at a current density of $40 \mathrm{~mA} \mathrm{~cm}{ }^{-2}$, and the corresponding $\mathrm{CE}, \mathrm{VE}, \mathrm{EE}$, and volumetric capacity are shown in Figure $4 \mathrm{~b}$. The CE remains between 80 and $90 \%$, and the $\mathrm{VE}$ is stable at above $80 \%$. The capacity initially decreases and then becomes stable and oscillates after 20 cycles. The initial decay is largely due to the crossover of free TEOA molecules. Such capacity decay is in agreement with observations in other Fe-TEOA-related RFBs. ${ }^{5,8}$ Admittedly, the volumetric capacity demonstrated in the cycle test is small due to the limited solubility of $\mathrm{Fe}(\mathrm{III}) / \mathrm{Fe}(\mathrm{II})-\mathrm{TEOA}^{5}$ and $\mathrm{Fe}(\mathrm{III}) / \mathrm{Fe}(\mathrm{II})-\mathrm{CN}^{20}$ The solubility of metal-ligand systems can be improved. For example, the solubility of $\mathrm{Fe}(\mathrm{III}) /$ $\mathrm{Fe}(\mathrm{II})-\mathrm{CN}$ was increased by using mixed metal cations $\left(\mathrm{K}^{+}\right.$

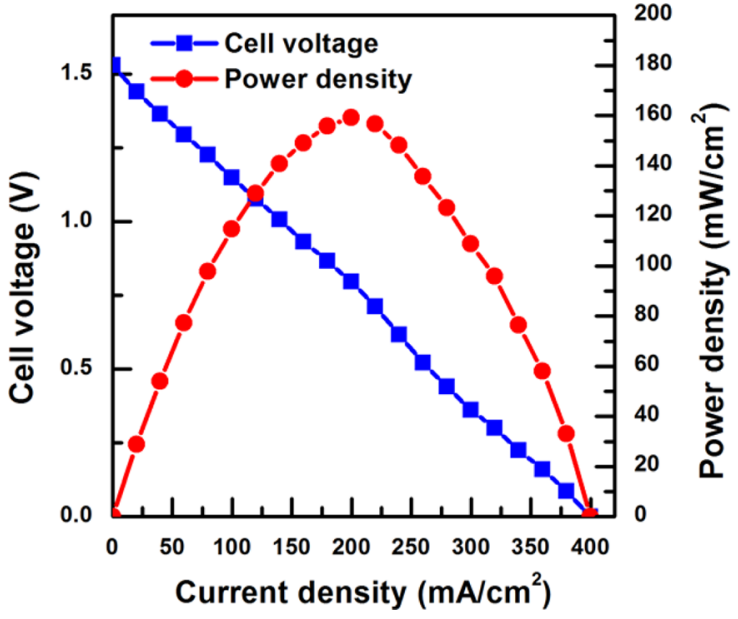

Figure 3. Polarization curve of the all-Fe RFB at a $70 \%$ state of charge (SOC) with the peak power density at $160 \mathrm{~mW} / \mathrm{cm}^{2}$. The polarization curve shows a strong ohmic relationship between the voltage and current density, indicating that the system is limited by internal resistance.
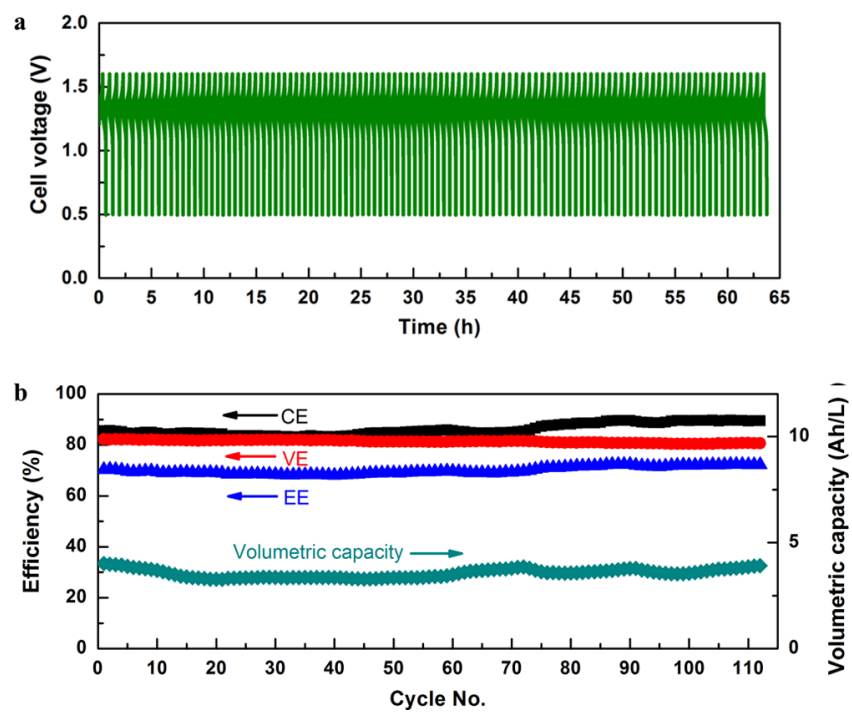

Figure 4. (a) Cell voltage during a 110-cycle test of an all-soluble all-Fe RFB at $40 \mathrm{~mA} / \mathrm{cm}^{2}$. (b) CE, VE, EE, and discharge capacity of each cycle in the same 110-cycle test of an all-soluble all-Fe RFB.

and $\mathrm{Na}^{+}$) in the supporting base, ${ }^{21}$ which warrants further study but is beyond the scope of this work.

Despite good performance and durability, two notable challenges, i.e., low CE and high cell resistance, are observed and investigated.

Relatively low CE observed in the cycle test was also reported in the literature for the Fe-TEOA redox pair. ${ }^{5,8}$ As shown in Figure S2, electrode potential measurement at the end of the discharge process reveals that the $\mathrm{Fe}(\mathrm{CN})_{6}{ }^{3-}$ / $\mathrm{Fe}(\mathrm{CN})_{6}^{4-}$ redox pair is the limiting side, which confirms that the shortage of oxidative species in the positive electrolyte is responsible for CE loss. The oxygen evolution reaction (OER) as a side reaction on the positive electrode can be excluded for the shortage of oxidative species; the symmetrical cell study of the $\mathrm{Fe}(\mathrm{CN})_{6}{ }^{3-} / \mathrm{Fe}(\mathrm{CN})_{6}{ }^{4-}$ redox pair did not show any $\mathrm{CE}$ loss $(\mathrm{CE}=100 \%$, Figure S3) even at high overpotential. The crossover of $\mathrm{Fe}(\mathrm{CN})_{6}^{3-}$ species toward the negative electrode can also be excluded; no new ${ }^{13} \mathrm{C}$ NMR signals were observed 
in the negative electrolyte after 20 cycles of testing (Figure S4a). The ${ }^{13} \mathrm{C}$ NMR spectra suggest that the permeation coefficient of $\mathrm{Fe}(\mathrm{CN})_{6}{ }^{3-}$ across a Nafion 212 membrane is less than $1 \times 10^{-11} \mathrm{~cm}^{2} \mathrm{~s}^{-1}$ (Figure S5). The crossover of $[\mathrm{Fe}(\mathrm{TEOA}) \mathrm{OH}]^{-},[\mathrm{Fe}(\mathrm{TEOA})(\mathrm{OH})]^{2-}$, and/or free TEOA in the negative electrolyte should be the key reason for CE loss, as evidenced by the ${ }^{13} \mathrm{C}$ NMR spectroscopic results of the positive electrolyte before and after the cycle test (Figure S4b). The permeation coefficients of $[\mathrm{Fe}(\mathrm{TEOA}) \mathrm{OH}]^{-},[\mathrm{Fe}(\mathrm{TEOA})$ $(\mathrm{OH})]^{2-}$, and TEOA are quantitatively studied with both ${ }^{13} \mathrm{C}$ NMR spectroscopy and inductively coupled plasma-optical emission spectrometry (ICP-OES, Figure S6). The results listed in Table 3 further confirm that the free TEOA molecule is the

Table 3. Permeation Coefficients of $[\mathrm{Fe}(\mathrm{TEOA}) \mathrm{OH}]^{-}$, $[\mathrm{Fe}(\mathrm{TEOA}) \mathrm{OH}]^{2-}$, and Free TEOA

\begin{tabular}{cccc} 
species & $\begin{array}{c}{[\mathrm{Fe}(\mathrm{TEOA})} \\
\mathrm{OH}]^{-}\end{array}$ & $\begin{array}{c}{[\mathrm{Fe}(\mathrm{TEOA})} \\
\mathrm{OH}]^{2-}\end{array}$ & free TEOA \\
$\begin{array}{c}\text { permeation coefficient } \\
\left(\mathrm{cm}^{2} \mathrm{~s}^{-1}\right)\end{array}$ & $5.1 \times 10^{-10}$ & $3.4 \times 10^{-10}$ & $1.5 \times 10^{-9}$ \\
\hline
\end{tabular}

major crossover species. This identification is understandable because the free TEOA molecule has a higher permeation coefficient (2.9-4.4 times) and larger driving force as well (5 times, $1 \mathrm{~mol} \mathrm{~L}^{-1}$ for free TEOA versus $0.2 \mathrm{~mol} \mathrm{~L}^{-1}$ for $[\mathrm{Fe}(\mathrm{TEOA}) \mathrm{OH}]^{-}$or $\left.[\mathrm{Fe}(\mathrm{TEOA})(\mathrm{OH})]^{2-}\right)$.

After crossover, the free TEOA could be oxidized either electrochemically on the electrode at high overpotentials or chemically by $\mathrm{Fe}(\mathrm{CN})_{6}{ }^{3-}$. The electrochemical oxidation of free TEOA is confirmed by the $\mathrm{CV}$ experiments in which an appreciable amount of anodic current is observed when the electrode potential is greater than $0.4 \mathrm{~V}$ versus $\mathrm{Ag} / \mathrm{AgCl}$ (Figure S7a), indicating the oxidation of free TEOA. The addition of free TEOA into the dilute $\mathrm{Na}_{4} \mathrm{Fe}(\mathrm{CN})_{6}$ solution significantly changed the $\mathrm{CV}$ behavior at the potential region below $0.4 \mathrm{~V}$ versus $\mathrm{Ag} / \mathrm{AgCl}$, suggesting that a direct chemical reaction between TEOA and $\mathrm{Fe}(\mathrm{CN})_{6}{ }^{3-}$ can also take place (Figure S7a). The possible chemical reactions between TEOA and $\mathrm{Fe}(\mathrm{CN})_{6}{ }^{3-}$ are proposed in eqs 3 and 4 and are represented in Scheme 1 . The reaction products were confirmed via ${ }^{1} \mathrm{H}$ NMR (Figure S8).

$$
2 \mathrm{Fe}(\mathrm{CN})_{6}^{3-}+\mathrm{TEOA}+2 \mathrm{OH}^{-} \stackrel{k}{\leftrightarrow} 2 \mathrm{Fe}(\mathrm{CN})_{6}^{4-}+\mathrm{diol}+\mathrm{H}_{2} \mathrm{O}
$$

$$
2 \mathrm{Fe}(\mathrm{CN})_{6}{ }^{3-}+\text { diol }+2 \mathrm{OH}^{-} \stackrel{k^{\prime}}{\leftrightarrow} 2 \mathrm{Fe}(\mathrm{CN})_{6}{ }^{4-}+\text { acetamide }+\mathrm{H}_{2} \mathrm{O}
$$

Here, diol represents 1-(bis(2-hydroxyethyl)amino)ethane-1,2diol, and acetamide represents 2-hydroxy-N,N-bis (2hydroxyethyl)acetamide. The overall rate constant of the reaction is determined to be $1.0 \times 10^{-7} \mathrm{~s}^{-1}$ assuming that the overall reaction is a first-order reaction (Figure S7b).

On the basis of the impedance test of the full cell, as shown in Figure S9a, the charge-transfer resistance is $0.75 \Omega \cdot \mathrm{cm}^{2}$. By contrast, the ohmic resistance observed $\left(2.6 \Omega \cdot \mathrm{cm}^{2}\right)$ is more than 3 times as large as the charge transfer resistance. The $i R$ free polarization was calculated and shown in Figure S9b, which demonstrates a peak power density near $800 \mathrm{~mW} \mathrm{~cm}^{-2}$. Our experimental cell has an MEA structure, and thus, the electrodes bring very small resistances. ${ }^{22}$ As such, the large membrane resistance is the major reason for this high internal resistance. The resistance of the Nafion 212 membrane was measured in a solution of $3 \mathrm{M} \mathrm{NaOH}$ solution, a solution containing $3 \mathrm{M} \mathrm{NaOH}$ and $2 \mathrm{M}$ TEOA, and a solution of $3 \mathrm{M}$ $\mathrm{NaOH}$ containing $2 \mathrm{M}$ TEOA and $0.4 \mathrm{M} \mathrm{FeCl}_{3}$. The results clearly show that both Fe-TEOA and free TEOA can contaminate the Nafion membrane, leading to increased membrane resistance, as shown in Figure S10. This result is not surprising because the absorption of alkylamine by a cationexchange membrane has also been widely reported in other applications such as carbon dioxide transport. ${ }^{23,24}$ It can be reasonably expected that TEOA-tolerant cation-exchange membranes will substantially improve the cell performance. Obviously, the development of such TEOA-tolerant cationexchange membranes is beyond the scope of our work here.

In summary, we introduced an all-soluble all-iron RFB by combining $[\mathrm{Fe}(\mathrm{TEOA}) \mathrm{OH}]^{-} /[\mathrm{Fe}(\mathrm{TEOA})(\mathrm{OH})]^{2-}$ and $\mathrm{Fe}-$ $(\mathrm{CN})_{6}{ }^{3-} / \mathrm{Fe}(\mathrm{CN})_{6}{ }^{4-}$ in a simple single-IEM cell configuration. The all-soluble all-Fe RFB demonstrated good performance (discharge power density $>160 \mathrm{~mW} \mathrm{~cm}^{-2}$ ) and durability $(110$ cycle test with stable efficiency and capacity). We identified that the major challenge in this all-soluble all-Fe RFB is the crossover of the free TEOA ligand. The performance of allsoluble all-Fe RFB may be improved by using TEOA-tolerant membranes. In addition to the all-soluble all-iron RFB, there

Scheme 1. Proposed Possible Reactions of TEOA Oxidation in $\mathrm{Fe}(\mathrm{CN})_{6}{ }^{3-}$ Electrolyte as Shown in Equations 3 and 4

a.<smiles>OCCN(CCO)CCO</smiles><smiles>[2H]OCCN(CCO)C(O)CO</smiles>
$\mathrm{OH}$

$\mathrm{OH}$

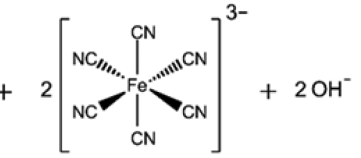
${ }^{-}$

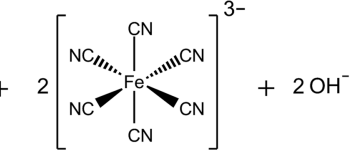

$2 \mathrm{OH}^{-}$<smiles>[Tl]</smiles>
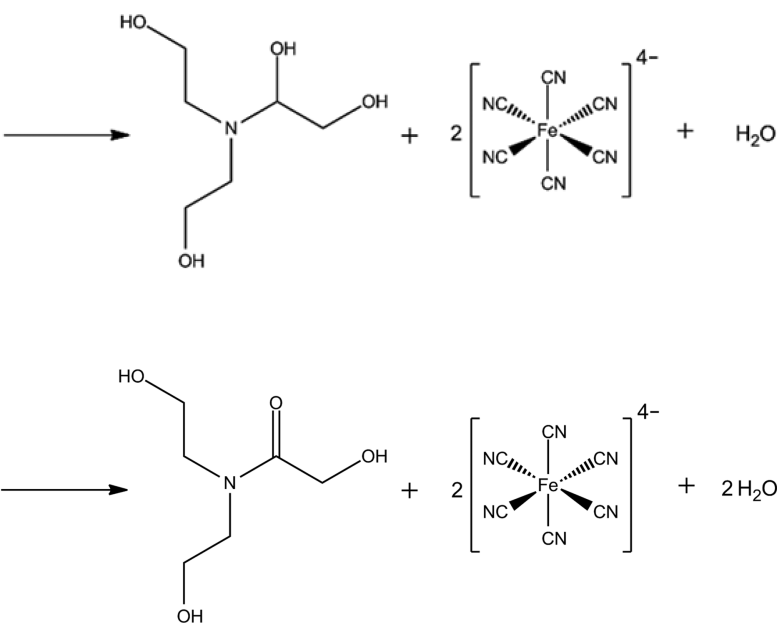
are many possibilities to design other all-soluble all-(redoxactive) element RFBs by using metal-ligands-based redox pairs, while caution should be exercised in choosing redox pairs with appropriate kinetics, voltage, and solubility for practical use.

\section{ASSOCIATED CONTENT}

\section{S Supporting Information}

The Supporting Information is available free of charge on the ACS Publications website at DOI: 10.1021/acsenergylett.6b00049.

Experimental methods, electrode potentials and standard rate constants, cyclic voltammetry plots, cell voltage curves, NMR spectra, impedance plots, polarization curves, and diagram of the cell configuration (PDF)

\section{AUTHOR INFORMATION}

\section{Corresponding Authors}

*E-mail: yanys@udel.edu (Y.S.Y.).

*E-mail: shuang.gu@wichita.edu (S.G.).

\section{Notes}

The authors declare no competing financial interest.

\section{ACKNOWLEDGMENTS}

This work was funded by the U.S. Department of Energy through ARPA-E Award (DE-AR0000346).

\section{REFERENCES}

(1) Yang, Z. G.; Zhang, J. L.; Kintner-Meyer, M. C. W.; Lu, X. C.; Choi, D. W.; Lemmon, J. P.; Liu, J. Electrochemical Energy Storage for Green Grid. Chem. Rev. 2011, 111, 3577-3613.

(2) Wang, W.; Luo, Q. T.; Li, B.; Wei, X. L.; Li, L. Y.; Yang, Z. G. Recent Progress in Redox Flow Battery Research and Development. Adv. Funct. Mater. 2013, 23, 970-986.

(3) Hagedorn, N. H. NASA Redox Storage System Development Project Final Report; National Aeronautics and Space Administration, Lewis Research Center: Cleveland, OH, 1984.

(4) Rychcik, M.; Skyllaskazacos, M. Characteristics of a New AllVanadium Redox Flow Battery. J. Power Sources 1988, 22, 59-67.

(5) Wen, Y. H.; Zhang, H. M.; Qian, P.; Zhou, H. T.; Zhao, P.; Yi, B. L.; Yang, Y. S. A Study of the $\mathrm{Fe}(\mathrm{III}) / \mathrm{Fe}$ (II)-Triethanolamine Complex Redox Couple for Redox Flow Battery Application. Electrochim. Acta 2006, 51, 3769-3775.

(6) Sanz, L.; Lloyd, D.; Magdalena, E.; Palma, J.; Kontturi, K. Description and Performance of a Novel Aqueous All-Copper Redox Flow Battery. J. Power Sources 2014, 268, 121-128.

(7) Peljo, P.; Lloyd, D.; Doan, N.; Majaneva, M.; Kontturi, K. Towards a Thermally Regenerative All-Copper Redox Flow Battery. Phys. Chem. Chem. Phys. 2014, 16, 2831-2835.

(8) Arroyo-Curras, N.; Hall, J. W.; Dick, J. E.; Jones, R. A.; Bard, A. J. An Alkaline Flow Battery Based on the Coordination Chemistry of Iron and Cobalt. J. Electrochem. Soc. 2015, 162, A378-A383.

(9) Hruska, L. W.; Savinell, R. F. Investigation of Factors Affecting Performance of the Iron-Redox Battery. J. Electrochem. Soc. 1981, 128, $18-25$.

(10) Chen, Y. W. D.; Santhanam, K. S. V.; Bard, A. J. Solution Redox Couples for Electrochemical Energy Storage: I. Iron (III)-Iron (II) Complexes with O-Phenanthroline and Related Ligands. J. Electrochem. Soc. 1981, 128, 1460-1467.

(11) Murthy, A. S. N.; Srivastava, T. Fe(III)/Fe(II) - Ligand Systems for Use as Negative Half-cells in Redox-Flow Cells. J. Power Sources 1989, 27, 119-126.

(12) Lockheed Palo Alto Research Lab. Rechargeable Alkaline Zinc Ferro-Ferricyanide Hybrid Redox Battery. J. Power Sources 1980, 5, 384-385.
(13) Wen, Y. H.; Zhang, H. M.; Qian, P.; Zhou, H. T.; Zhao, P.; Yi, B. L.; Yang, Y. S. Studies on Iron $\left(\mathrm{Fe}^{3+} / \mathrm{Fe}^{2+}\right)$-Complex/Bromine $\left(\mathrm{Br}_{2} / \mathrm{Br}^{-}\right)$Redox Flow Cell in Sodium Acetate Solution. J. Electrochem. Soc. 2006, 153, A929-A934.

(14) Hawthorne, K. L.; Wainright, J. S.; Savinell, R. F. Studies of Iron-Ligand Complexes for an All-Iron Flow Battery Application. J. Electrochem. Soc. 2014, 161, A1662-A1671.

(15) Holze, R. Landolt-Börnstein: Numerical Data and Functional Relationships in Science and Technology, Electrochemical Thermodynamics and Kinetics; Springer: Berlin Heidelberg, Germany, 2007.

(16) Hilbert, F.; Miyoshi, Y.; Eichkorn, G.; Lorenz, W. J. Correlations between the Kinetics of Electrolytic Dissolution and Deposition of Iron: I. The Anodic Dissolution of Iron. J. Electrochem. Soc. 1971, 118, 1919-1926.

(17) Gu, S.; Gong, K.; Yan, E. Z.; Yan, Y. S. A Multiple Ion-Exchange Membrane Design for Redox Flow Batteries. Energy Environ. Sci. 2014, 7, 2986-2998.

(18) Gong, K.; Ma, X.; Conforti, K. M.; Kuttler, K. J.; Grunewald, J. B.; Yeager, K. L.; Bazant, M. Z.; Gu, S.; Yan, Y. S. A Zinc-Iron RedoxFlow Battery under $\$ 100$ per $\mathrm{kW}$ h of System Capital Cost. Energy Environ. Sci. 2015, 8, 2941-2945.

(19) Kolthoff, I. M.; Tomsicek, W. J. The Oxidation Potential of the System Potassium Ferrocyanide-Potassium Ferricyanide at Various Ionic Strengths. J. Phys. Chem. 1934, 39, 945-954.

(20) Adams, G. B.; Hollandsworth, R. P.; Webber, B. D. Rechargeable Alkaline Zinc/Ferricyanide Battery; Lockheed Palo Alto Research Laboratory: Palo Alto, CA, 1979.

(21) Trant, C.; Vercillo, P.; Jorne, J.; Zhou, D. Solubility of Sodium Ferrocyanide and Potassium Ferrocyanide in Solutions of $\mathrm{NaOH}$ and $\mathrm{KOH}$ Mixtures at $25 \mathrm{C}$. University of Rochester, 2011.

(22) Aaron, D. S.; Liu, Q.; Tang, Z.; Grim, G. M.; Papandrew, A. B.; Turhan, A.; Zawodzinski, T. A.; Mench, M. M. Dramatic Performance Gains in Vanadium Redox Flow Batteries Through Modified Cell Architecture. J. Power Sources 2012, 206, 450-453.

(23) Yamaguchi, T.; Boetje, L. M.; Koval, C. A.; Noble, R. D.; Bowman, C. N. Transport-Properties of Carbon-Dioxide through Amine Functionalized Carrier Membranes. Ind. Eng. Chem. Res. 1995, 34, 4071-4077.

(24) Yamaguchi, T.; Koval, C. A.; Noble, R. D.; Bowman, C. N. Transport Mechanism of Carbon Dioxide Through Perfluorosulfonate Ionomer Membranes Containing an Amine Carrier. Chem. Eng. Sci. 1996, 51, 4781-4789. 